\title{
Developing Task Based Language Teaching Worksheet as the Solution in Teaching and Learning English
}

\author{
Suci Azani Putri ${ }^{*}$ and Refnaldi ${ }^{2}$ \\ ${ }^{12}$ Universitas Negeri Padang, Padang and Indonesia \\ *Corresponding author. Email: suciazaniputri@gmail.com
}

\begin{abstract}
Worksheet is common used as supplementary teaching materials in teaching and learning English. It provides interesting tasks which cannot be found in text book. Worksheet facilitates teacher to make an existing classroom activity through completing the tasks. This paper tries to explore the use of task based language teaching approach which writer believes brings the variety of tasks into classroom activities. Task based language teaching approach presents multiple tasks such as real task and pedagogic task, unfocused task and focused task, input based task and output based task, and closed and opened task. These tasks will offer the students to uses whatever language they know to accomplish the tasks. However, the existing of appropriate worksheet is infrequent in teaching and learning process. Teachers are difficult to prepare appropriate worksheet that suitable with students' need. Some worksheet might be interesting, but do not meet students' characteristics and abilities. By using task based language teaching approach, it is expected that teachers are able to develop their own interesting worksheet. The worksheet can be developed based on the need of the students and the shapes of teachers' classrooms. Task based language teaching worksheet is hoped to be used as alternative ways for teacher in making communicative teaching and learning process.
\end{abstract}

Keywords: task based language teaching, worksheet, teaching and learning English

\section{INTRODUCTION}

The fact that appropriate worksheet is a neglected in teaching and learning English cannot be denied. Some teachers are difficult to create interesting worksheet that meets students' needs. Teachers need such thing as innovation to overcome this problem in order to make interesting teaching and learning classroom. This paper will discuss the use of task based language teaching approach to make students worksheet.

The use of task based language teaching is not new in foreign language teaching or second language teaching. Task based language teaching approach is current approach that used to make students actively engage in classroom activities through completing the task. This approach usually implemented by the teacher to improve students English skills in teaching learning. Task-Based approach is used in improving the students' speaking accuracy and fluency and shows that it is an appropriate method to improve learners' speaking skill [1]. It is clear that the use of TBLT approach has been widely declare as a common approach for language teaching and learning.

Moreover, task based language teaching also used as approach to develop teaching materials. The first is supplementary speaking materials using task based language teaching for Primary school in Yogyakarta context [2]. Then, English writing materials using Task-
Based Language Teaching for the tenth grade students of Senior High School [3]. The materials are developed by TBLT helps teachers and students achieve the goal of learning.

According to the previous studies, the need of TBLT as approach to make a worksheet is arise. Worksheet as one of teaching materials needs to be developed. The available worksheet does not help teachers and students yet achieve the aims of teaching and learning. However, the development of students' worksheet needed to facilitate the achievement of learning objectives expected. The students' achievement in one school of Taiwan is increased when they taught by using teaching material development accordance to the needs of students. Using students' worksheets in learning process are expected can significantly improve students' outcomes. Thus, learning by using appropriate students' worksheet will supports learning process [4].

Furthermore, developing task based language teaching worksheet become new challenges for teachers. It needs teacher creativity and understanding about task based language teaching. Teachers need to explore their imagination to make innovative, creative and motivating worksheet to the students. Trough creating their own worksheet, teachers are independent to shape their class using the worksheet. They are able to create worksheet that appropriate to their students' abilities and characteristics. 
Thus, the application of task based language teaching approach in developing worksheet could possibly become solution for teacher to make interesting classroom activity.

\section{RELEVANT THEORETICAL REVIEW} 2.1 The Use of Worksheet in Teaching and Learning English

\section{The Use of Worksheet in Teaching and learning}

Worksheet is one of printed teaching materials that assist teachers to accomplish the goal of learning. Worksheet is exercises or activities which are drawn, written or word processed and photocopied [5]. Through worksheet, teachers engage students in organized steps to reach the objective of learning. In addition, worksheet defines as crucial tools involving the steps of process what the students should do next, help the students set their information in their mind while ask the whole class to participate in the given activity [6] Further, when the students are asked to write what they know and learn in worksheet, they must achieve cognitive activities as they return back. It other word, worksheet helps students understanding learning through doing the worksheet.

In addition, according to research of Ikhsan and SB (2016), there are two components of worksheet; cover of worksheet and sheet of worksheet. The cover should be written in English. The sheet of worksheet includes header (department, course, topic, and time allocation), objectives, activities, materials (the concepts and theory about instructional media) and tasks [7]. Next, Azizi in her research (2014) present several components of worksheet. The first is pre-introduction. It is prepreliminary components before entering to study. It consists of front cover as the name of students worksheet, preface, list of content, and detailed of standard of competency, basic competence and indicators. The second is introduction. It is beginning of learning activities that aim to provide information materials to be learned and the learning objective to be achieved. This consists of concept map; a diagram that shows the concepts that represents learning. The third is content. It includes entire discussions of materials contained on student's worksheet. The last is complementary. It is additional information which has been linked to the material [8].

\section{Worksheet development}

Worksheet becomes essential element in teaching learning materials. As one of the homegrown materials, it should be legible, clear, attractive and durable in order to use it more than once [9]. In writing worksheet, there are five stages that should be followed by the designers proposed by Harmer. The first is planning. This stage will decide the aim, objective, activities and the content of the worksheet. The clarity of them can moved designer on producing the materials.
The second is trialing. It is expected that other can figures mistakes or ambiguities of the worksheet. It is important to try out the materials before bringing it to the classroom. The third is evaluating. After producing and trialing, designer will use it in the classroom. Through observing it carefully, designers can evaluate the worksheet as a result they know how and when they use it in the future. The fourth is classifying. It is the sequences of the worksheet which can be depending on topic, vocabulary area, etc. The last is record-keeping. It needs to keep a record of what materials have used together with evaluation of how well it has worked. It prevents from using same materials twice with the same classes.

Furthermore, there are several steps in writing worksheet. The first is curriculum analysis. It is intended to determine subject matter requires worksheet as teaching material. It carries out through studying the standards competencies, basic competencies, subject matter, learning experiences, and indicators of the achievement of learning outcomes. The second is making a map of worksheet needs. It is intended to know the number of worksheet that must be written and the sequence $\mathrm{o}$ of the worksheets can also be seen. This sequence of worksheet is needed in determining the priority of writing. The third is determining the titles of worksheet. It based on basic competencies or basic material contained in the curriculum. One basic competency can be used as one title of worksheet.

The fourth is writing the worksheet. There are several steps in making a worksheet. The first is formulating the basic competence that must be mastered by the students. It is derived from syllabus document. The second is determining the assessment of work process and students' works. It carried out through the process and students' works. The third is arranging the material based on basic competencies of materials. Material can be taken from any sources such thing as book, magazine, internet or journals. The last is structures of worksheet. In general, the structures of worksheet are title, study instruction, competencies to be achieved, task and procedure of task and assessment [10].

\subsection{Task Based Language Teaching Approach in Teaching and Learning}

Task Based Language Teaching (TBLT) is an innovative language teaching method that offers language experience in the classroom. It presents students opportunities to actively engage in communication in order to accomplish a goal or complete the task. TBLT is an approach which is based on assumption that accuracy is acquired after fluency or after successful communication [11]. To get accuracy in English, the students have to develop their communication skills. Trough TBLT which stands with tasks, it is expected that students have more chances to build their language meaningful and communication skills. There will be 
several tasks is provided in TBLT which teach students' accuracies.

In addition, TBLT is known as an approach based on the use of tasks as the core unit and planning instruction in language teaching [12]. TBLT is believed as the basis of English teaching and learning. The process of teaching and learning is built through the tasks. Tasks being a center which creates students center learning. Tasks will guide and help students to understand the subject. Furthermore, task-based language teaching defines as an approach to language teaching organized around tasks rather than language structures. TBLT makes students complete the tasks than not stressing on language structure [13].

\subsubsection{Types of Task based language Teaching}

Nunan distinguish task into two types, they are target task and pedagogical task. Target task refers to the use of language in the real world activities outside school setting. This task has a non-linguistic outcome and some of them may not present language use at all. On the other hand, when the real task transformed into classroom tasks, it is called as pedagogical tasks. Pedagogical task is the use of language during the classroom activities or in a piece of classroom works. Pedagogical tasks as a piece of classroom work that engage learners in comprehending, manipulating, producing or interacting in the target language while their attention is focused on activate their grammatical knowledge in order to express meaning. It emphasizes on conveying meaning rather than manipulating form. It means students using target language they know to achieve the goal of task which stressing meaning than structure in pedagogical tasks.

Moreover, Ellis proposes two types of task; unfocused task and focused task. Unfocused task is task designed that offers learners opportunities for using language in general communicatively. It encourages students to use English freely to communicate. On the other hand, focused task is task designed to provide opportunities for communicating using some specific linguistic feature (typically a grammatical structure). However, the target linguistic feature of a focused task is hidden. Hence, unfocused task is language for general communication, where focused task is language by using some linguistic features [14]. Additionally, Ellis also divided two types of task based on the complexity of task; Input based task and output based task. Input based task do not require production of language, but engage learner during task work. This emphasizes on listening and reading skill. Later, output based task requires learner to produce the language through completing the task. This focuses on speaking and writing [15].

Furthermore, Willis proposes two types of tasks in TBLT; closed and open tasks. Closed tasks are tasks that highly structure and have very specific goals. The instruction of this task is detail and the information is limited. It formulates one possible outcome and one way to achieve the outcome. While open tasks are tasks that loosely structured with less specific aim. It will make more than possible way to achieve the outcomes. The instruction will be not detail and general.

\subsubsection{Framework of Task based language Teaching}

Willis proposes three stages of TBLT, namely pre-task, task cycle and language focus. Pre task raises students' consciousness and introduce the students about the topic and the task. The teacher explores the topic to the students, highlights useful words and phrases and assists them to understand task instruction. Teachers can lead the students through pictures, recordings or texts. The next step is task cycle where has three stages within; task, planning and report. In task stages, the students do the tasks, it can be pairs or small groups. The students are free to experiment without teachers' intervention. Mistakes are no matter, the students are free to use the target language. In the planning stages, students prepare to report how they do the task and what they discover to the whole classes, it can be orally or written. Students are able to request teachers' help for language advice, as they report publicly and they need for sure it will be accurate.

The last is report. Report is the part of students presenting, result of their discussion, or result of comparing to others. Language focus is the last step of TBLT framework which has two parts within; analysis and practice. When analysis is ongoing, the students examine and discuss the specific features of the text or transcript of recording. They can add new words, phrases, and pattern in vocabulary book. Afterwards, teacher will conduct practice of new words, phrases, and patterns occur the data either during or after analysis.

Moreover, Munirah and Muhsin present taskbased learning framework into three steps; pre-task, task cycle and language focus. In pre-task, learners are prepared to perform task in ways that promote acquisition. It presents topic and task. In task-cycle, the stage divided into task stage, the planning stage and the reporting stage. Task stage is a goal of task. Learner will practice using language skills while the teacher monitors and encourages them. The planning stage is the central part of the task cycle. It presents how to help learners plan their report effectively. Learners are prepared to report to the class how they accomplish the task and what they discovered or decided. In this stage, the teacher will make sure that the purpose of report is clear, acts as language adviser and helps learner practice oral reports or organize written reports. The reporting stage concludes the task cycle. During this stage, students take full notes on language use plus responses and reactions to the language. The students present their oral reports to the class or display their written reports. Teacher will acts as chairperson who choose who speak and read the reports and also give feedback to the report. The last step is language focus. There are three major pedagogic goals in this step; providing an opportunity for repeated 
performance of the task, encouraging reflection on how the task was performed and to encouraging attention to form, in particular to problematic forms which demonstrate when students have accomplished the task.

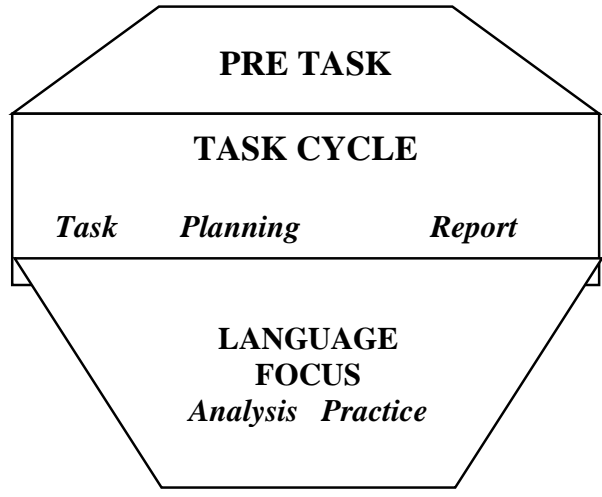

Figure 1: Framework of Task-Based Language Teaching (Willis, 1996:52)

\section{DISCUSSION}

3.1 Task Based Language Teaching Worksheet as solution in Teaching and Learning English

3.1.1 Presenting Multiple Tasks into Classroom Activities

Task is an activity that requires learners to arrive at an outcome from given information through some process of thought and which allows teachers to control and regulate that process [16]. It is classroom activity or exercise that has objective obtainable only by interaction among participants, a mechanism for structuring and sequencing interaction and focus meaning exchange [17]. It asks students achieving goal of learning trough communicatively activities. It involves teacher and students to actively engage in activities based on the roles.

Besides, task can be defined as a range of work plans which have the overall purposes of facilitating language learning from simple and brief exercise type to more complex and lengthy activities such as group problem solving or simulations and decision making [18]. Willis (1996) proposes task as activity in which target language is used for a communicative purpose to achieve an outcome. In other words, tasks are multiple activities where language is used to achieve the aim of learning.

In addition, a task is an activity that requires learners to use language with emphasis on meaning to attain objective. It supports by Nunan who defines task as a piece of classroom work that involves learners in comprehending, manipulating, producing or interacting in the target language while their attention is principally focused on meaning rather than form. Thus, task in language learning highlight meaning than the form of task itself. While doing the task, the meaning of task become the core of task given.

\subsubsection{Giving chance for Students to actively engage in the} classroom

Task based language teaching asked students to complete the tasks by using their language resources. It can be linguistic resources and non-linguistic resources. The students are free to use both of them as long they are able to do the tasks. The main point in task based language teaching worksheet is not on grammatical structure but on the meaning of the task. The mistaken are acceptable, but the goal of teaching and learning should be reached through the tasks.

\subsubsection{Giving chance for Teacher to be creative and} innovative in making teaching material

Some teaching materials are not appropriate with the students. The problems might come from students' abilities, characteristics or students' motivation. To overcome these problems, teachers are demanding to create and develop their own worksheet. The development of worksheet can be based on the need of the students. The tasks are provided in the worksheet can be made in creative, innovative and communicative so that students can accomplish it. It also motivates the students face new way to learn English. They might do variety of tasks, but they are able to enjoy it because offering new challenges for them,

\section{CONCLUSION}

Task based language teaching is a common approach that used in EFL/ESL. This approach can be used an approach to develop teaching materials, one of them is worksheet. Teachers are demanding to create their own worksheet in order to create new innovation in teaching and learning. Worksheet that created by teachers can be solution for variety of characteristics and abilities of students, Teachers who understand the students are able to create the worksheet based on the need of their classes. Even though task based language teaching worksheet is not the only teaching materials which used in teaching and learning English, it probably could be preference for teacher in developing their own worksheet.

\section{ACKNOWLEDGMENT}

I would like to thank to Dr. Refnaldi, S.Pd, M.Litt. from UNP who guided the writer and given contribution to this paper, and also to the anonymous reviewers who have given valuable feedback.

\section{REFERENCES}

[1] Munirah \& M. A., Muhsin, Using Task-Based Approach in Improving the Students' Speaking Accuracy and Fluency. Journal of Education and Human Development, 4(3), 181-190, 2015.

[2] R. B., Wulan, Supplementary Speaking Materials Using Task Based Language Teaching for Primary 
School in Yogyakarta Context. Journal of English Language and Pedagogy, 2(1), 77-83, 2019.

[3] K., Indraswari, Developing Supplementary English Writing Materials Using Task-Based Language Teaching for the Tenth Grade Students of Senior High School (Doctoral dissertation, YOGYAKARTA STATE UNIVERSITY), 2015.

[4] Y.T., Chen, and Y. T., Li, Development and Evaluation of Multimedia Reciprocal Representation Instructional Material. International Journal of the Physical Sciences. 6(6):1431-1439,2011.

[5] J., Brewster, G., Ellis, \& D., Girard, The Primary English Teacher's Guide (New Edition). Harlow: Pearson Education Limited, pp.37-49, 2002.

[6] D., Celikler, \& Z., Aksan, The Effect of The Use Of Worksheets About Aqueous Solution Reactions On Pre-Service Elementary Science Teachers' Academic Success. Procedia-Social and Behavioral Sciences, 4611-4614, 2012.

[7] J., Harmer, The Practice of English Language Teaching. Completely revised and updated. Malaysia: Longman, 2002.

[8] M., Ikhsan, Khairi; SB, Handayani. The Developmentof Students' worksheet Using Scientific Approach on Curriculum Materials. Proceedings of ISELT FBS Universitas Negeri Padang, 4.2: 74-87, 2016.

[9] A. N., Azizi, Developing Students' Worksheet of Science on Earth and Universe With Asmaul Husna Approach to Improve Learning Achievement of Fourth Grade Students of Islamic Elementary School of Salafiyah Khairudin Gondanglegi Malang. (Doctoral dissertation, Universitas Islam Negeri Maulana Malik Ibrahim), 2014.

[10] DEPDIKNAS. Panduan Pengembangan Bahan Ajar. Jakarta: Direktorat Jendral Manajemen Pendidikan Dasar dan Menengah, 2008.

[11] D. A., Willis, Framework for Task-Based Learning. London: Longman, 1996.

[12] C. Richard, \& T. Rodger, Approach and Methods in Language Teaching Second Edition. New York: Cambridge University Press, 2001.

[13] D. Nunan, Task-Based Language Teaching. Cambridge: Cambridge University Press, 2004.

[14] R. Ellis, Task-Based Language Learning and Teaching. Oxford: Oxford University Press,2003.

[15] R. Ellis, Task-Based Language Teaching: Sorting Out the Misunderstanding. International Journal of Applied Linguistics. Vol 19. No.3,2009.

[16] N. S. Prabhu, Second Language Pedagogy (Vol. 20). Oxford: Oxford University Press, 1978.

[17] U. Sae-ong, The Used of Task-based Learning and Group Work Incorporating to Develop English Speaking Ability". Thailand: Shrinakhrinwirot University, 2010.

[18] M. Breen, Learner Contribution to Task Design. In C. Cadlin and D Murphy (eds), Language Learning
Task (pp.23-46). Englewood Cliffs, NJ: Prentice Hall,1987. 